\title{
The Hepatitis B Virus Core Variants that Expose Foreign C-Terminal Insertions on the Outer Surface of Virus-Like Particles
}

\author{
Andris Dishlers $^{1} \cdot$ Dace Skrastina $^{1} \cdot$ Regina Renhofa $^{1} \cdot$ Ivars Petrovskis $^{1}$. \\ Velta Ose $^{1} \cdot$ Ilva Lieknina $^{1} \cdot$ Juris Jansons $^{1} \cdot$ Paul Pumpens $^{1} \cdot$ Irina Sominskaya $^{1}$
}

Published online: 7 October 2015

(c) The Author(s) 2015. This article is published with open access at Springerlink.com

\begin{abstract}
The major immunodominant region (MIR) and $\mathrm{N}$-terminus of the hepatitis B virus (HBV) core (HBc) protein were used to expose foreign insertions on the outer surface of $\mathrm{HBc}$ virus-like particles (VLPs). The additions to the $\mathrm{HBc}$ positively charged arginine-rich $\mathrm{C}$-terminal (CT) domain are usually not exposed on the VLP surface. Here, we constructed a set of recombinant $\mathrm{HBcG}$ vectors in which CT arginine stretches were substituted by glycine residues. In contrast to natural HBc VLPs and recombinant $\mathrm{HBc}$ VLP variants carrying native CT domain, the HBcG VLPs demonstrated a lowered capability to pack bacterial RNA during expression in Escherichia coli cells. The C-terminal addition of a model foreign epitope from the $\mathrm{HBV}$ preS1 sequence to the $\mathrm{HBcG}$ vectors resulted in the exposure of the inserted epitope on the VLP surface, whereas the same preS1 sequences added to the native $\mathrm{CT}$ of the natural $\mathrm{HBc}$ protein remained buried within the $\mathrm{HBc}$ VLPs. Based on the immunisation of mice, the preS1 epitope added to the $\mathrm{HBcG}$ vectors as a part of preS1(20-47) and preS1phil sequences demonstrated remarkable immunogenicity. The same epitope added to the original C-terminus of the $\mathrm{HBc}$ protein did not induce a notable level of anti-preS1 antibodies. HBcG vectors may contribute to the further development of versatile $\mathrm{HBc}$ VLP-based vaccine and gene therapy applications.
\end{abstract}

Irina Sominskaya

Irina@biomed.lu.lv

1 Protein Engineering Department, Latvian Biomedical Research and Study Centre, Ratsupites Str 1, Riga 1067, Latvia
Keywords Hepatitis B virus - Core protein - C-terminal domain · preS1 sequence $\cdot$ Immunogenicity $\cdot$ Virus-like particles

\section{Introduction}

Hepatitis B virus (HBV) core (HBc) virus-like particles (VLPs) are one of the oldest [1-3] and the most powerful protein engineering tools utilised to (i) expose immunological epitopes and/or cell-targeting signals and (ii) package poly- and oligonucleotides as genes and immune stimulatory sequences (for review see [3-8]). HBc VLPs and their numerous derivatives are efficiently produced in bacterial and yeast expression systems (for references see [5-8]). Novel advanced purification and packaging protocols permit the highly technological production and efficient quality control of recombinant HBc-derived VLPs [9].

Bacteria-produced HBc VLPs are represented by two isomorphs with triangulation numbers $T=4$ and 3 that consist of 240 and $180 \mathrm{HBc}$ monomers and are 35 and $32 \mathrm{~nm}$ in diameter, respectively [10]. The three-dimensional structure of the $T=4$ particles was resolved by $\mathrm{X}$-ray crystallography [11], whereas a quasi-atomic pattern of the $T=3$ isomorph was reconstructed by docking the dimers of the $T=4$ crystal structure [12]. Analogous HBc VLP structures have been produced in other efficient heterologous expression systems, including yeast $S$. cerevisiae $[13,14]$ and $P$. pastoris $[15,16]$.

The $\mathrm{HBc}$ protein consists of two linearly separated domains: (i) the N-terminal self-assembly (SA) domain at amino acid (aa) residues 1-140, which is necessary and sufficient for the protein to self-assemble and result in the structure revealed by X-ray [11], and (ii) the protamine-like 
arginine-rich C-terminal (CT) domain at aa 150-183 [17], whose three-dimensional structure is unresolved. The SA and CT domains are separated by a hinge peptide 141-149 $[18,19]$.

The SA domain involves the so-called major immunodominant region (MIR), the most protruding aa residues 78-82 of which are located on the tips of the HBc spikes [11]. The MIR is generally used for the insertion of foreign $B$ cell epitopes to maximally expose these epitopes on the VLP surface and consequently provide the most efficient immunogenic activity (for review see [4-6]).

During HBV life cycle, the CT domain is primarily responsible for the encapsidation of the 3.5-kilobase pregenomic $\mathrm{HBV}$ mRNA, which is converted further into partially double-stranded HBV DNA (for a recent review see [20]) and is dispensable for self-assembly [21]. Therefore, so-called $\mathrm{HBc} \Delta$ particles fully deprived of the CT domain or carrying shortened CT domain fragments are highly efficiently synthesised in bacteria and are consequently often used as the preferred HBc carriers [22].

The nucleic acid-binding sites in the CT domain are organised into four arginine blocks [23] that are buried within HBc VLPs [24]. Although some data demonstrate that CT domain elements may appear on the HBc VLP surface [25-27], the C-terminal insertions of foreign epitopes, in contrast to the MIR and N-terminal insertions, demonstrate generally low immunogenicity in experimental animals (for more detail see [4, 5, 28]). However, the extremely high capacity of the C-terminal insertions [29] has inspired further attempts to elucidate their potential applicability.

In this study, we constructed a novel class of HBc VLP carriers, so-called $\mathrm{HBcG}$ vectors, in which arginine residues of the CT domain are fully or partially replaced by glycine residues. The elimination of positively charged CT stretches in the $\mathrm{HBcG}$ carriers prevents the encapsidation of bacterial RNA by cultivation in Escherichia coli and allows the exposure of a C-terminally inserted model epitope, namely, the major epitope of the HBV preS1 sequence, onto the outer surface of $\mathrm{HBcG}$-derived VLPs. This exposure markedly improves the immunogenicity of the inserted epitope in experimental animals.

\section{Materials and Methods}

\section{Bacterial Strains}

Two E. coli strains-E. coli $\mathrm{K} 802\left(\mathrm{~F}^{-} \mathrm{r}_{\mathrm{K}}^{-} \mathrm{m}_{\mathrm{K}}^{+}\right.$e14 McrA metB1lac Y1 [or lacI-Y6] galK2 galT22 glnV44 mcrB) and $\mathrm{BL} 21$ [ $\mathrm{F}^{-}$ompT hsdSB ( $\left.\mathrm{rB}^{-} \mathrm{mB}^{-}\right)$gal dcm lon] were used to produce VLPs.

\section{Construction of Plasmids for the Expression of HBc- and HBcG-Derived Constructions}

Two original plasmids were used to construct "one-tail" HBc variants: pHBc183, which expresses the full-length $\mathrm{HBc}$ gene [22], and $\mathrm{pHBcG}$, in which all $\mathrm{HBc}$ arginine codons starting at position 150 were replaced with glycine codons (primers not shown). For C-terminal insertions into both HBc vectors, a Bsp1407I site was introduced after the 183 aa position within the $\mathrm{HBc}$ gene using a site-directed mutagenesis kit (Agilent Technologies, Santa Clara, CA, USA) and primers Bsp 1407Ifor and Bsp1407Irev (Table 1). The obtained plasmids were named pHBc183T and pHBcGT for variants with $\mathrm{HBc}$ or $\mathrm{HBcG}$ genes, respectively. The preS1(30-36) fragment was obtained via the annealing of two primers, DPAFR-Bsp1407Ifor and DPAFR-Bsp1407Irev, which were then cloned into the

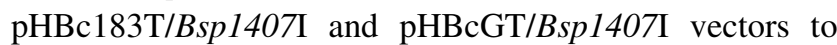
yield plasmids pHBc-S1(31-35) and pHBcG-S1(31-35), respectively (Fig. 1). The preS1(20-47) and preS1phil (containing preS1 regions 12-60 and 89-119) coding fragments were obtained by PCR using primers 5, 6 and 7, 8 (Table 1) and plasmid pHBc $\Delta$-pre-S1(20-47) for fragment preS1(20-47) and plasmid pHBc $\Delta$-pre-S1phil for fragment pre-S1phil, respectively [30, 31]. The PCR fragments were treated with Bsp1407I and cloned into the Bsp1407I-treated vectors $\mathrm{pHBc} 183 \mathrm{~T}$ and $\mathrm{HBcGT}$, resulting in plasmids pHBc-S1(20-47), pHBc-S1phil, pHBcGS1(20-47), and pHBcG-S1phil (Fig. 1). To generate constructs based on $\mathrm{HBc}$ in which the first or first two arginine blocks are retained at the $\mathrm{HBc} \mathrm{C}$-terminus, site-directed mutagenesis was performed using plasmid $\mathrm{pHBcG}-$ S1(20-47) and pHBcG-S1phil and primers 9 and 10 (Table 1) to obtain plasmids $\mathrm{pHBcG}_{-1}-\mathrm{S} 1(20-47)$ and $\mathrm{pHBcG}_{-1}-\mathrm{S} 1$ phil. Site-directed mutagenesis with the latter plasmids and primers 11 and 12 (Table 1) resulted in plasmids $\mathrm{pHBcG}_{-2}-\mathrm{S} 1(20-47)$ and $\mathrm{pHBcG}_{-2}-\mathrm{S} 1$ phil, respectively. The $\mathrm{pHBc} 183$ plasmid was used for "twotail" constructs based on $\mathrm{HBc}$ with a C-terminal extension-the last cysteine codon in this plasmid was substituted by a serine codon, and an additional serine codon was added followed by a coding sequence for aa 144-183 of $\mathrm{HBc}$ in which arginine codons were substituted by glycine codons. An Ecl136II site was introduced to clone this second glycine-containing "tail," which resulted in the pHBcEcl136II plasmid. Treating pHBcEcl136II and pHBcG-S1(20-47) with Bsp1407//SacI yielded the pHBcGly-S1(20-47) plasmid, and treating pHBcEcl136II and pHBcG-S1phil with Bsp1407I/Bsp68I yielded the pHBcGly-S1phil plasmid. All enzymes were from Thermo Fisher Scientific (Waltham, MA, USA). 
Table 1 List of primers used for plasmid construction

\begin{tabular}{lll}
\hline 1 & Bsp1407Ifor & $5^{\prime}$ GAATCTCAATGTACATAGTAAGGATCCT \\
2 & Bsp1407Irev & $5^{\prime}$ AGGATCCTTACTATGTACATTGAGATTC \\
3 & DPAFR-Bsp1407for & 5'GTACAGATCCAGCCTTCAGGTAGTAAT \\
4 & DPAFR-Bsp1407rev & 5'GTACATTACTACCTGAAGGCTGGATCT \\
5 & Bsp1407I 20-47for & 5'CTCAATGTACAAATCCTCTGGGATTCTTTCCCGACCACCAGTTG \\
6 & Bsp1407I 20-47rev & 5'CTATGTACATTACTAGGGATTGAAGTCCCAATCTGGATTTGC \\
7 & Bsp1407I preS1for & 5'CTCAATGTACAATGGGGCAGAATCTTTCCA \\
8 & Bsp1407I preS1rev & 5'CTATGTACATTACTAAGCCTGAGGATGAGTGTTTCTCA \\
9 & SPRR1for & $5^{\prime}$ GACTACTGTTGTTCGTCGTCGTGGCCGTTCCCCT \\
10 & SPRR1rev & $5^{\prime}$ AGGGGAACGGCCACGACGACGAACAACAGTAGTC \\
11 & SPRR2for & $5^{\prime}$ GGCCGTTCCCCTCGTCGTCGTACTCCCTCGCC \\
12 & SPRR2rev & $5^{\prime}$ GGCGAGGGAGTACGACGACGAGGGGAACGGCC \\
13 & Ecl136IIfor & $5^{\prime}$ CTCGTGAATCTCAGAGCTCAGGAATCTGTACATAGTAAG \\
14 & Ecl136IIrev & $5^{\prime}$ CTTACTATGTACAGATTCCTGAGCTCTGAGATTCACGAG \\
\hline
\end{tabular}

C-terminal part of HBc-derived vectors:

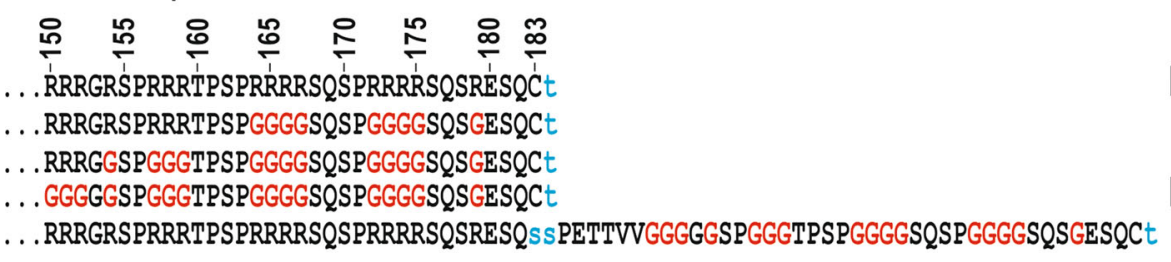

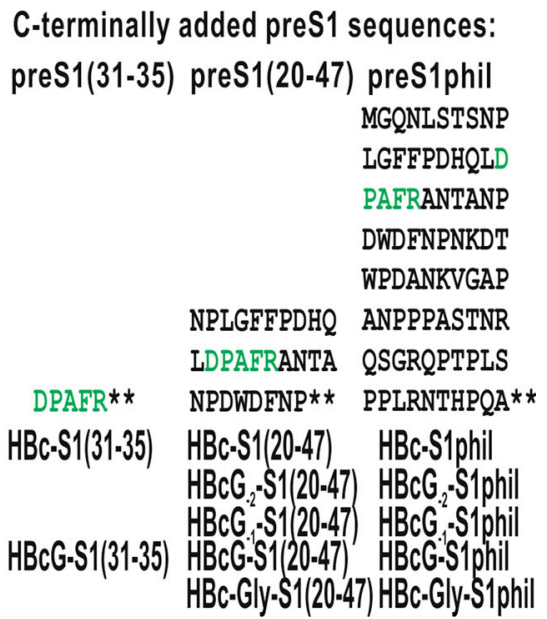

Fig. 1 Schematic representation of the HBc- and HBcG-based derivatives carrying three forms of the preS1 epitope. The glycine substitutions are shown in red, the aa linkers that are not present in the original sequences are indicated in lowercase blue

\section{Expression of Recombinant Genes and Purification of VLPs}

The cells were cultivated in Trp-deficient M9 salt medium (M9-cas) supplemented with $1 \%$ casamino acids, and $0.2 \%$ glucose (BD, Franklin Lakes, NJ, USA), Ap, and $\mathrm{Km}$ (at 50 and $10 \mu \mathrm{g} / \mathrm{mL}$, respectively) without an additional induction of Ptrp or in $2 \times \mathrm{TY}$ medium containing $20 \mu \mathrm{g} / \mathrm{mL}$ ampicillin and supplemented with $2 \mathrm{~g}$ glucose, $3.47 \mathrm{~g} \mathrm{KH}_{2} \mathrm{PO}_{4}$, and $18.8 \mathrm{~g} \mathrm{~K}_{2} \mathrm{HPO}_{4}$ per litre $(2 \times \mathrm{TY}+\mathrm{P})$. The aeration of the medium was ensured by incubating $750 \mathrm{~mL}$ Erlenmeyer flasks filled with $300 \mathrm{~mL}$ of medium on an orbital shaker at $200 \mathrm{rpm}$. The cultures were incubated for $14-16 \mathrm{~h}$ at $37{ }^{\circ} \mathrm{C}$ and allowed to reach a final OD540 of 5-8 or 8-10 (in M9-cas media or $2 \times \mathrm{TY}+\mathrm{P}$ media, respectively).

To assess $\mathrm{HBc}$ protein synthesis, 2 OD units of cells were pelleted and lysed in $200 \mu \mathrm{L}$ of Laemmli buffer for
10 min at $100{ }^{\circ} \mathrm{C}$, and $10 \mu \mathrm{L}$ of the lysate was subjected to SDS-PAGE.

The VLPs were purified from wet fresh cells according to basic methods published elsewhere [10] with some modifications specific to the groups of VLPs. The first group of chimeric VLPs based on wt HBc (named as HBcderived proteins) and the $\mathrm{HBcs}$ containing arginine substitutions by glycine in all arginine blocks (named as $\mathrm{HBcG}$-derived proteins) were purified as follows: $2 \mathrm{~g}$ of wet fresh cells was incubated for $30 \mathrm{~min}$ on ice in $8 \mathrm{~mL}$ of lysis buffer containing $50 \mathrm{mM}$ Tris- $\mathrm{HCl}, \mathrm{pH} 8.0,5 \mathrm{mM}$ EDTA, $50 \mu \mathrm{g} / \mathrm{mL}$ PMSF, $0.5 \mathrm{M}$ urea, and $0.1 \%$ Triton $\mathrm{X}-100$. The suspension was ultrasonicated five times at $22 \mathrm{kHz}$ at 15 -s intervals on ice. After clarification at $7000 \mathrm{rpm}$ for $10 \mathrm{~min}$, the supernatant was incubated at $50{ }^{\circ} \mathrm{C}$ for $30 \mathrm{~min}$, repeatedly centrifuged at $7000 \mathrm{rpm}$ for 15 min and loaded onto a Sepharose CL-4B column or Sephacryl S-1000 column $(2.5 \times 85 \mathrm{~cm})$. PBS buffer 
without Triton X-100 was used for elution. The HBccontaining fractions (detected by SDS-PAGE) were pooled, and the proteins were precipitated by centrifugation at 52,000 rpm on Beckman $70 \mathrm{Ti}$ rotor for $60 \mathrm{~min}$ at $4{ }^{\circ} \mathrm{C}$. The resultant pellet was dissolved in $40 \mathrm{mM}$ phosphate buffer supplemented with $\mathrm{NaCl}$ to a final concentration of $150 \mathrm{mM}$. Proteins with final concentrations of $10-20 \mathrm{mg} /$ $\mathrm{mL}$ in $50 \%$ glycerol were stored at $-20{ }^{\circ} \mathrm{C}$ until use. A second group of chimeric VLPs based on HBc containing one arginine block (first of four arginine blocks, named $\mathrm{HBcG}_{-1}$-derived proteins) and two arginine blocks (first two of four arginine blocks, named $\mathrm{HBcG}_{-2}$-derived proteins) at the C-end were purified as follows: $8 \mathrm{~g}$ of wet fresh cells was resuspended in 4 volumes of the lysis buffer (50 mM Tris- $\mathrm{HCl}, \mathrm{pH} 8.0,5 \mathrm{mM}$ EDTA, $150 \mathrm{mM} \mathrm{NaCl}$, $50 \mu \mathrm{M}$ PMSF, and $0.1 \%$ Triton X-100) and ultrasonicated 8 times at $22 \mathrm{kHz}$ for $10 \mathrm{~s}$. After clarification of the lysate at $10,000 \times \mathrm{g}$ for $30 \mathrm{~min}$, the soluble proteins were precipitated with $10 \%$ ammonium sulphate at $4{ }^{\circ} \mathrm{C}$ for $1 \mathrm{~h}$, followed by centrifugation at $10,000 \times g$ for $30 \mathrm{~min}$. VLPs in the supernatant were precipitated with $35 \%$ ammonium sulphate at $4{ }^{\circ} \mathrm{C}$ overnight, followed by centrifugation at $10,000 \times g$ for $30 \mathrm{~min}$. The sediment was dissolved in $15 \mathrm{~mL}$ of PBS buffer containing $0.5 \mathrm{M}$ urea and $50 \mu \mathrm{M}$ PMSF and subjected to size-exclusion chromatography on a Sepharose 4 Fast Flow (GE Healthcare, Sweden) $320 \mathrm{~mL}$ column $(25 \times 850 \mathrm{~mm})$ at a flow rate of $0.5 \mathrm{~mL} / \mathrm{min}$.

The semi-preparative purification the HBcG-S1phil for the detailed immunological characterisation was performed as follows: $9 \mathrm{~g}$ of wet fresh K802 cells was incubated for $30 \mathrm{~min}$ on ice in $36 \mathrm{~mL}$ of lysis buffer containing $50 \mathrm{mM}$ Tris-HCl, pH 8.0, $5 \mathrm{mM}$ EDTA, $50 \mu \mathrm{g} / \mathrm{mL}$ PMSF, and $0.1 \%$ Triton $\mathrm{X}-100$. The suspension was ultrasonicated five times at $22 \mathrm{kHz}$ at 15 -s intervals on ice. After centrifugation at $12,000 \mathrm{rpm}$ for $60 \mathrm{~min}, 40 \mathrm{~mL}$ of the lysate was obtained and supplemented with $\mathrm{NaCl}$ to a final concentration of $0.5 \mathrm{M}$ and $40 \%$ PEG8000 water solution at a ratio 3:1, i.e. $13.3 \mathrm{~mL}$. After an overnight incubation, the HBcG-S1phil VLPs were extracted from the pellet using small consecutive aliquots of NET buffer $(20 \mathrm{mM}$ Tris$\mathrm{HCl}, \mathrm{pH} 7.8,5 \mathrm{mM}$ EDTA, and $0.15 \mathrm{M} \mathrm{NaCl}$ ). Sixteen millilitres of the extract was loaded onto a Sepharose CL4B column $(2.5 \times 85 \mathrm{~cm})$ and eluted with the NET buffer. The VLP-containing fractions $(58 \mathrm{~mL}$ in total) collected after the PAGE analysis were supplemented with ammonium sulphate to $60 \%$ saturation. The mixture was incubated at $4{ }^{\circ} \mathrm{C}$ overnight. The pellet obtained after centrifugation at 10,000 rpm for 30 min was resuspended in $3 \mathrm{~mL}$ of $0.1 \mathrm{M} \mathrm{Na}_{2} \mathrm{CO}_{3}$ and $2 \mathrm{mM}$ DTT, loaded onto a Sephacryl S300 (GE Healthcare Europe GmbH Suomen sivuliike, Helsinki, Finland) column $(1 \times 50 \mathrm{~cm})$, and eluted using the same solution of $0.1 \mathrm{M} \mathrm{Na}_{2} \mathrm{CO}_{3}$ and $2 \mathrm{mM}$ DTT at a velocity of $1.2 \mathrm{~mL} / \mathrm{h}(60 \mathrm{~min} / 1.2 \mathrm{~mL}$ fraction $)$.
The VLP-containing fractions were identified using OD measurements and PAGE and pooled. A carbonate-neutralising buffer (250 mM HEPES, $500 \mathrm{mM} \mathrm{NaCl}, 10 \mathrm{mM}$ DTT, and $300 \mathrm{mM} \mathrm{MgCl} 2$ at $\mathrm{pH}$ 4.6) was added in an amount $1 / 4$ th of the fraction volume. For storage, half the material was dialysed against the NET buffer with glycerol at a volume/volume ratio of $1: 1$, and the remaining half was precipitated by adding ammonium sulphate to $50 \%$ saturation for $20 \mathrm{~h}$ at $4{ }^{\circ} \mathrm{C}$ (for more details see [9]). One day before the first immunisation or following boosts, 1-mL portions of the HBcG-S1phil VLPs were gel filtered on an analytical Sepharose CL-4B column $(0.8 \times 32 \mathrm{~cm})$. The VLP quality in the pooled fractions was controlled by electron microscopy prior to the immunisation of mice.

The "two-tail" VLPs, i.e. HBc-Gly-S1(20-47) and HBcGly-S1phil, were purified as described for the second group of proteins (see above) or as described for HBcG-S1phil, omitting the precipitation by ammonium sulphate of the gel filtration fractions. Although both methods produced particles of similar size according to dynamic light scattering (DLS), VLPs obtained using the second method were less aggregated according to the electron microscopy (EM) tests; these particles were also more reactive in a competitive ELISA than particles obtained by the first method.

\section{Detection of Protein and Nucleic Acids}

The protein concentration was generally determined using the Bradford method. The amount of HBc-Gly-S1(20-47) and HBc-Gly-S1phil proteins used for the competitive ELISA was estimated according to [32]. The Vector NTI 10.0.1 (Thermo Fisher Scientific, Waltham, MA, USA) software package was used to calculate that one optical absorbance unit of empty VLPs corresponds to $0.71 \mathrm{mg}$ of $\mathrm{HBc}$ protein.

For native agarose gel electrophoresis (NAGE), the samples were resolved in $1 \%$ UltraPure agarose (Thermo Fisher Scientific, Waltham, MA, USA) in TBE buffer, and the gels were subsequently stained. Specifically, the gels were first stained with ethidium bromide ( $5 \mu \mathrm{L}$ of a $10 \mathrm{mg} /$ $\mathrm{mL}$ stock in $100 \mathrm{~mL}$ of PBS) and then with Coomassie Blue R-250 (60 $\mu \mathrm{g} / \mathrm{mL}$ of Coomassie Blue R-250 in $10 \%$ acetic acid). All chemicals were obtained from SigmaAldrich (St. Louis, MO, USA).

The protein samples were analysed on $15 \%$ SDS-PAGE gels in a Tris-glycine-SDS system with subsequent Coomassie or silver staining according to standard procedures (LKB Laboratory Manual).

\section{Electron Microscopy and Dynamic Light Scattering Analysis}

For electron microscopy, VLPs in PBS were adsorbed to carbon-formvar-coated copper grids and negatively stained 
with a $1 \%$ aqueous solution of uranyl acetate. The grids were examined using a JEM-1230 electron microscope at $100 \mathrm{kV}$ or a JEM-100C electron microscope at $80 \mathrm{kV}$ (both Jeol Ltd., Tokyo, Japan).

The DLS analysis was performed on a Zetasizer Nano ZS instrument (Malvern Instruments Ltd, Malvern, UK). The results were analysed using the DTS software (Malvern, version 6.32).

\section{Antigenicity Test}

For the competitive ELISA, 96-well microplates were coated with preS1 peptide p20-47 using $100 \mu \mathrm{L}$ of peptide solution $(10 \mu \mathrm{g} / \mathrm{mL})$ per well. After incubation overnight at $4{ }^{\circ} \mathrm{C}$, the plates were blocked with $1 \%$ BSA in PBS for $30 \mathrm{~min}$ at $37^{\circ} \mathrm{C}$. Subsequently, $50-\mu \mathrm{L}$ aliquots of serial dilutions of competing protein and $50 \mu \mathrm{L}$ of the monoclonal antibody MA18/7 [33] were simultaneously added to the wells; to this end, the MA18/7 dilution was used, which resulted in an OD492 value within the range of $0.5-0.6$ for the control sample (without competing protein). After incubation for $1 \mathrm{~h}$ at $37^{\circ} \mathrm{C}$, the plates were washed three times with PBS containing $0.05 \%$ of Tween-20. Thereafter, $100 \mu \mathrm{L}$ of horseradish peroxidase-conjugated antimouse antibody (Sigma-Aldrich St. Louis, MO, USA) was added at a 1:10,000 dilution. After incubation for $1 \mathrm{~h}$ at $37{ }^{\circ} \mathrm{C}$, the plates were washed as before, and OPD substrate (Sigma-Aldrich St. Louis, MO, USA) was added to develop the colour. The per cent inhibition (I\%) of antibody binding by the competing protein was calculated as follows:

$I \%=$

[(OD492 test sample - OD492 negative control)/

(OD492 positive control - OD492 negative control)]

$\times 100$.

The molar amounts of the proteins necessary for $50 \%$ inhibition $\left(I_{50}\right)$ were calculated.

\section{Immunisation of Mice}

Female BALB/c mice aged 6-8 weeks were obtained from the Latvian Experimental Animal Laboratory (LEAL) at the Riga Stradins University (Latvia). The mice were allocated to groups (five mice per group) and subjected to immunisation by all proteins. Mice from Taconic Biosciences (Hudson, NY, USA) were used for immunisations with $\mathrm{HBcG}-\mathrm{S} 1$ phil formulated in different adjuvants. The animals were maintained at the Latvian Biomedical Research and Study Centre under pathogen-free conditions. The experiments were approved by the Latvian Animal
Protection Ethics Committee and the Latvian Food and Veterinary service (Permission No. 31/23.10.2010). Mice obtained from LEAL were subcutaneously immunised on days 0,14 , and 28 with $25 \mu \mathrm{g}$ of protein in PBS formulated with $250 \mu \mathrm{g}$ Alhydrogel in a total volume of $0.2 \mathrm{~mL}$ per mouse. Mice obtained from TAC were subcutaneously (s.c.) or intraperitoneally (i.p.) immunised with $25 \mu \mathrm{g}$ of $\mathrm{HBcG}-\mathrm{S} 1$ phil (in PBS) formulated with adjuvants in a total volume of $0.2 \mathrm{~mL}$, using PBS to normalise the volume. The following adjuvants were used in this experiment: $250 \mu \mathrm{g}$ of Ahydrogel for group A (Brenntag Biosector, Frederikssund, Denmark), $250 \mu \mathrm{g}$ of Silica for group B (Sigma-Aldrich St. Louis, MO, USA), Complete Freund's adjuvant (Sigma-Aldrich St. Louis, MO, USA) for the first injection and Incomplete Freund's adjuvant for the following two injections for group $\mathrm{C}$, and Incomplete Freund's adjuvant for all three injections for group D. To immunise mice in groups $\mathrm{C}$ and $\mathrm{D}$, the protein was mixed with adjuvant at a $v / v$ ratio of $1: 1$. Group $\mathrm{E}$ of mice was immunised with protein in PBS without any adjuvant. The mice were injected on days 0,14 , and 28 , and sera were collected on day 42 from mice sacrificed by cervical dislocation. The anti-HBc and anti-preS1 titres in the sera were determined with a direct ELISA using plates coated with the full-length $\mathrm{HBc}$ protein or preS1 peptide p20-47. The end-point titres were defined as the highest serum dilution that resulted in an absorbance value three times greater than that of the control sera obtained from unimmunised mice.

\section{Statistical Analysis}

Statistical analysis was performed by t test that compares the means of two groups (GraphPad Software, http://www. graphpad.com/quickcalcs/ttest1/). Significance levels are indicated by $p ; p$ values $<0.05$ were considered significant.

\section{Results}

\section{Construction of a Set of the HBcG Vectors and Preparation of HBc- and HBcG-Derived VLPs}

Figure 1 presents the structure of the $\mathrm{HBcG}$ vectors based on the HBc protein from the HBV320 genome (genotype D1, subtype ayw2, GenBank accession number X0249675) [34], which included the added preS1 sequences, as well as the parallel paired preS1-carrying constructs based on the natural $\mathrm{HBc}$. The $\mathrm{HBcG}$ vectors can be divided into four categories: (i) all four C-terminal arginine stretches are replaced by glycine residues, (ii) the first arginine stretch is preserved, (iii) the two first arginine stretches are 
preserved, or (iv) the natural C-terminus is prolonged by the C-terminal sequence with fully replaced arginine stretches.

The $\mathrm{HBcG}$ vectors and the paired HBc-based constructs are provided with the major virus-neutralising preS1 epitope 31-DPAFR-35 [35, 36] that is recognised by the monoclonal MA18/7 antibody [33]. The preS1 epitope is used in three different forms: (i) the pure epitope, which corresponds to aa residues $31-35$, (ii) the $20-47$ aa sequence that extends the epitope from both sides, and (iii) the preS1phil structure that contains preS1 fragments 12-60 and 89-119 aa, which corresponds to the full-length hydrophilic component of the preS1 sequence from the HBV320 genome but lacks the hydrophobic preS1 stretch at aa $61-88$ [30].

The HBcG-preS1 VLPs and the analogous HBc-preS1 VLP paired constructs were produced in E. coli and purified using a combination of traditional column chromatography methods. The VLP preparations demonstrated high consistency based on native agarose gel electrophoresis (NAGE) (not shown) and SDS-PAGE analysis (Fig. 2). In all cases, the DLS measurements revealed VLP diameters of approximately $35 \mathrm{~nm}$, in accordance with the expected size (not shown). The EM analysis revealed the high quality of HBcG-derived VLPs. (Fig. 3). The VLPs formed by HBc-Gly-S1(20-47), especially the HBc-GlyS1phil constructs that contained two C-terminal "tails," demonstrated a definite predisposition to aggregation.

As expected, the NAGE and UV spectra of the purified VLP preparations indicated the presence of the packaged bacterial RNA for $\mathrm{HBc}$-derived proteins, which contain a natural arginine-rich CT domain, and this bacterial RNA was absent when arginine residues were replaced by glycine residues (not shown).

\section{Location of the C-terminally Added preS1 Epitope on the HBc- and HBcG-Derived VLPs}

The antigenicity of the HBcG-preS1 VLPs and accessibility of the inserted preS1 epitope to the specific antibody was characterised using a competitive ELISA with the monoclonal MA18/7 antibody and compared to the antigenicity of the appropriately paired HBc-preS1 constructs (Fig. 4). The chimeric HBc VLPs carrying the preS1(20-47) epitope insertion at the MIR were used as control. The HBcG-S1(20-47) demonstrated a competition level that was very similar to that of the chimeric $\mathrm{HBc}$ VLPs carrying preS1 insertions within the MIR. The HBcG-S1phil competed to a slightly lesser extent, but this competition was, nevertheless, more efficient than that of the paired construct, $\mathrm{HBc}-\mathrm{S} 1$ phil. The competition lag of HBcG-S1phil compared to HBcG-S1(20-47) may be due to the remarkable length of the added preS1 sequence (80 aa); where specifically, the preS1 epitope $31-35$ is located at the $\mathrm{N}$-terminal part of the addition and can consequently be shielded by the C-terminal part of the addition. The HBcG-preS1 VLPs carrying the shortest version of the preS1 epitope, namely, aa residues 31-35, do not demonstrate any competition for MA18/7 antibodies, and this behaviour is similar to that of the HBc VLPs that lack preS1 insertions, which served as a negative control (not shown).

\section{Immunogenicity of the HBcG-Derived VLPs in Mice}

The HBcG-derived VLPs carrying the preS1(20-47) and preS1phil sequences demonstrated much higher anti-preS1 antibody responses in mice than did the paired $\mathrm{HBc}$ derived VLPs (Fig. 5). Specifically, the latter did not
Fig. 2 SDS-PAGE analysis of the purified $\mathrm{HBc}$ - and $\mathrm{HBcG}-$ derived VLPs

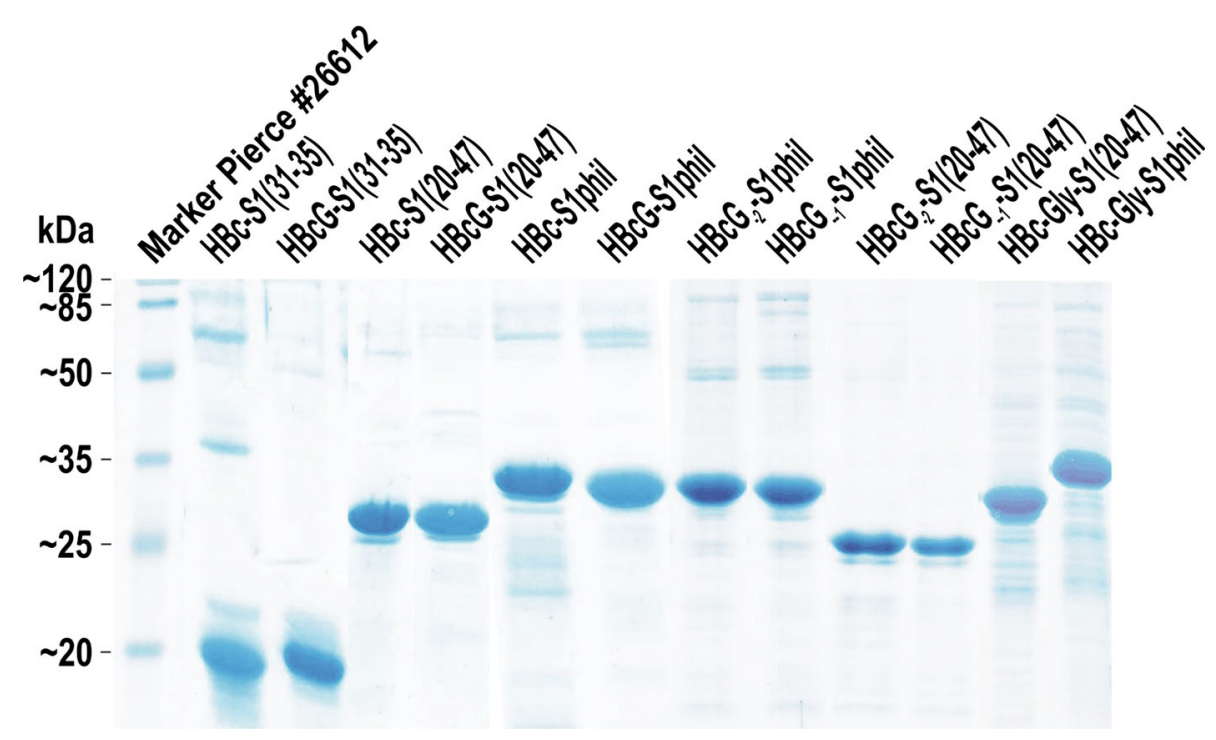



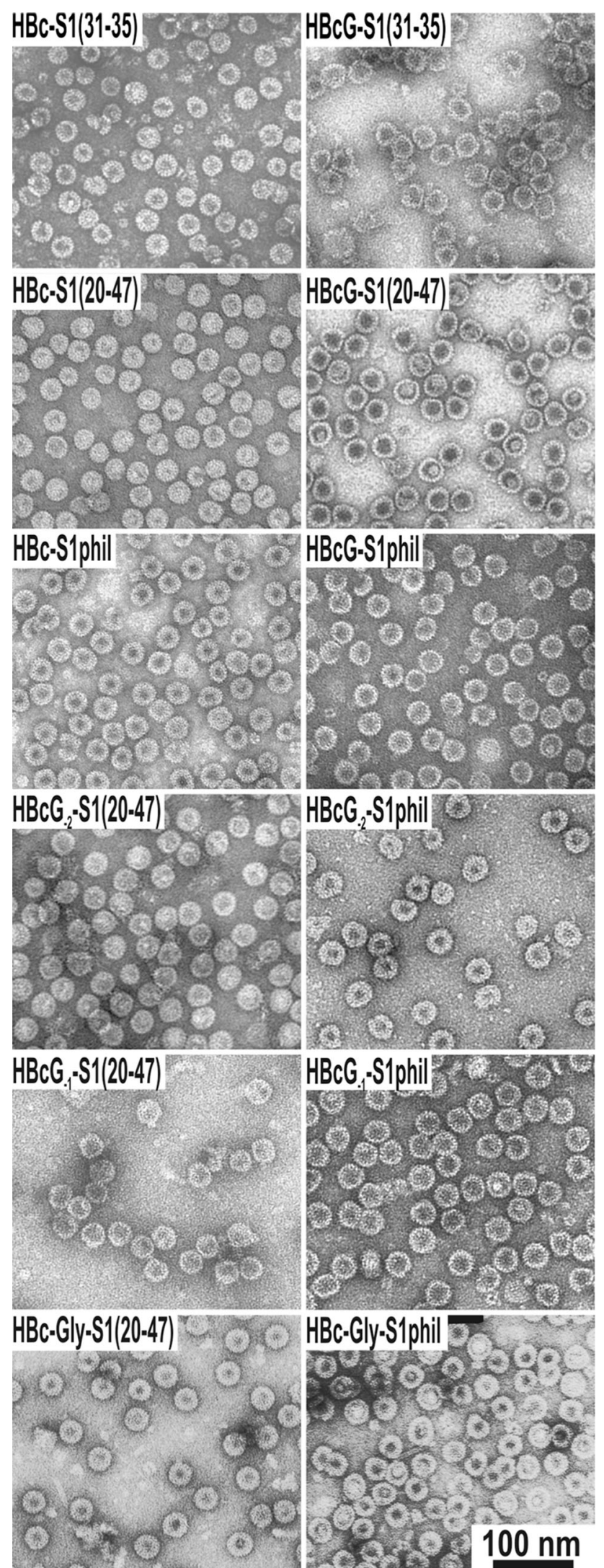

Fig. 3 Electron microscopy analysis of the purified HBc- and HBcGderived VLPs

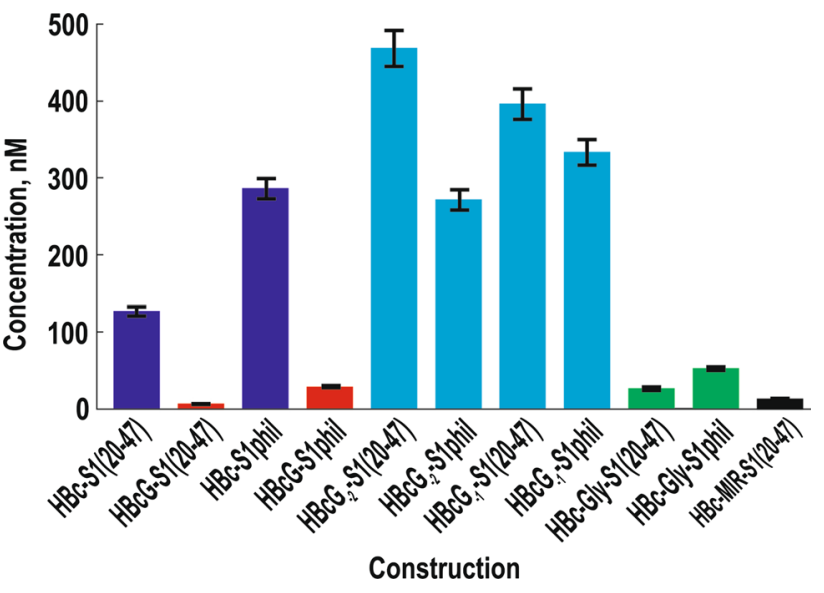

Fig. 4 The preS1 antigenicity of the VLPs formed on the basis of the $\mathrm{HBc}$ and $\mathrm{HBcG}$ vectors. The VLP concentrations necessary and sufficient to inhibit $50 \%$ of the binding of MA18/7 to the $20-47$ peptide on the support during the competitive ELISA. Tests were done in triplicate. Significance of differences between all of groups was less than 0.035 . The bars for VLPs based on HBc-, HBcG-, and two-tail HBc-Gly-derived vectors are shown blue, red, and green, respectively. The bars for VLPs based on partially replaced arginine stretches are shown in light blue. The bar for the HBc-MIR-derived construction that served as a control is shown black

induce remarkable anti-preS1 antibody levels. The HBcGS1(20-47) VLPs induced higher anti-preS1 titres than the HBcG-S1phil; this finding correlated well with the antigenicity data, which demonstrated that the accessibility of the preS1 epitope was improved over the native state. The anti-preS1 antibody titres and the ratio of the preS1(20-47) and preS1phil additions were similar for the constructs in which the C-terminal sequence with fully replaced arginine residues followed the natural $\mathrm{HBc} \mathrm{C}$-terminus, i.e. constructs HBc-Gly-S1(20-47) and HBc-Gly-S1phil. The constructs in which the first arginine stretch $\left(\mathrm{HBcG}_{-1}\right.$ S1phil) and two first arginine stretches $\left(\mathrm{HBcG}_{-2}-\mathrm{S} 1 \mathrm{phil}\right)$ were preserved elicited lower anti-preS1 responses than the VLPs that contained the fully substituted arginine residues at the $\mathrm{C}$-terminus.

Generally, the anti-preS1 response elicited by HBcGderived VLPs carrying preS1(20-47) and preS1phil sequences was comparable to the responses induced by analogous constructs carrying the respective preS1 sequences within the MIR (Fig. 5).

The HBcG-S1(31-35) VLPs and the paired HBcS1(31-35) were able to elicit only very low anti-preS1 antibody responses (Fig. 5).

The anti-HBc response induced by HBcG-derived VLPs did not markedly differ from the anti-HBc response induced by native HBc VLPs (Fig. 5).

The HBcG-S1phil VLPs were selected for the further detailed immunogenicity testing based on alternate immunisation routes and different adjuvant protocols (Fig. 6). First, the resultant data show that the 


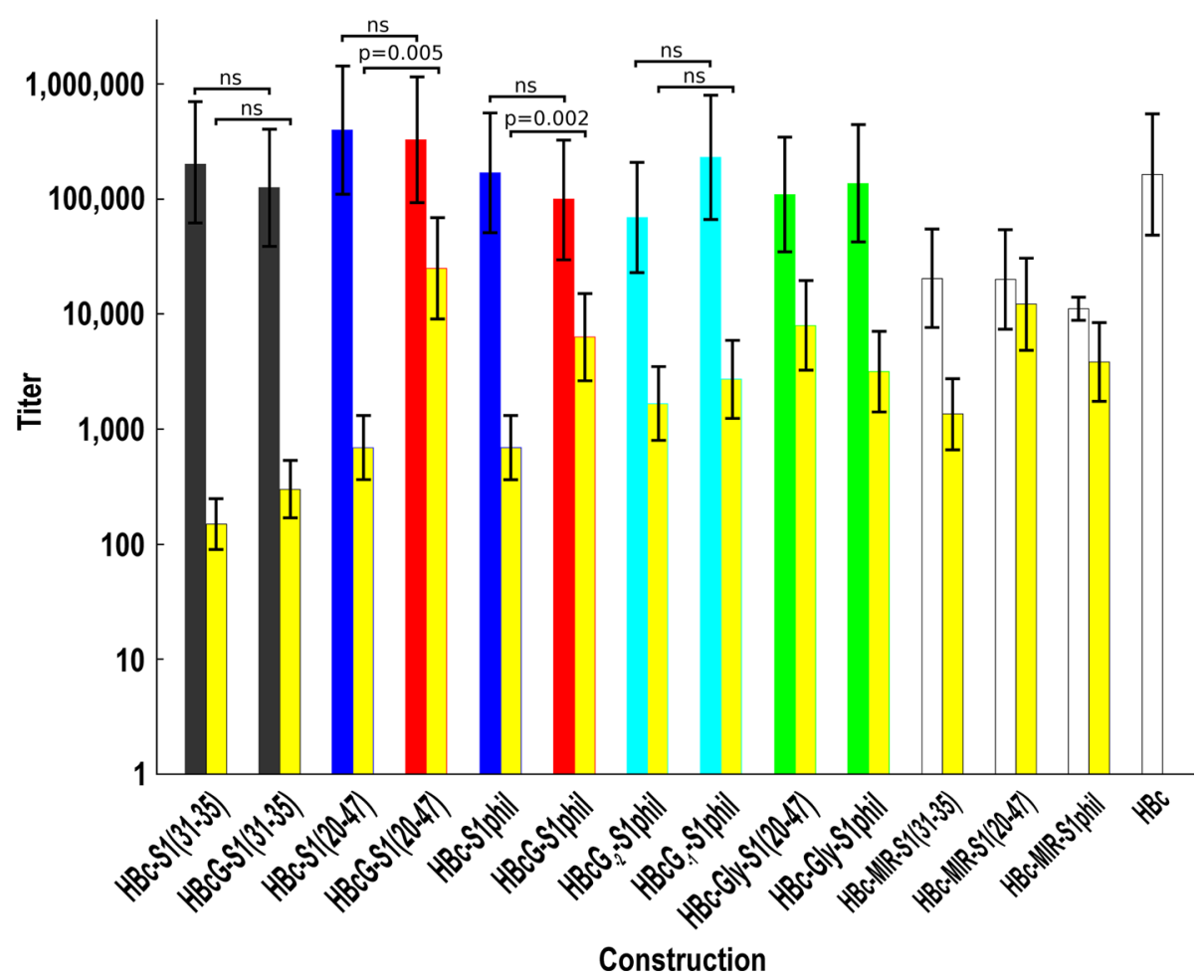

Fig. 5 The immunogenicity of a set of the HBcG-derived VLPs compared with that of the appropriate HBc-derived VLP pairs and $\mathrm{HBc}$ VLPs carrying preS1 insertions within the MIR. Mice obtained from LEAL were immunised with Alhydrogel adjuvant as stated in the "Materials and Methods" section. The colour of the anti-HBc bars corresponds to that used in Fig. 4 for the respective constructs. The anti-HBc bars for the constructs carrying preS1(31-35) sequences are grey. The anti-HBc bars corresponding to $\mathrm{HBc}-\mathrm{MIR}$ derived constructs and to the $\mathrm{HBc}$ without any insertions are white. The anti-preS1 bars are yellow but are outlined by a coloured contour corresponding to the construct in question. The presented results are the mean values $( \pm \mathrm{SD})$ of five individual mouse sera. Significance levels for paired constructs are indicated by $p, n s$ nonsignificant
Fig. 6 The immunogenicity of the HBcG-S1phil VLPs by different adjuvanting conditions and immunisation routes. Mice obtained from TAC were immunised with different adjuvants as stated in the "Materials and Methods" section. The colour of the anti$\mathrm{HBc}$ bars is red. The colour of the anti-preS1 (20-47) bars is yellow. The presented results are the mean values $( \pm \mathrm{SD})$ of five individual mouse sera. Significance of differences between groups with adjuvants and PBS group was assessed at the highest dilution and are indicated by $p, n s$ nonsignificant

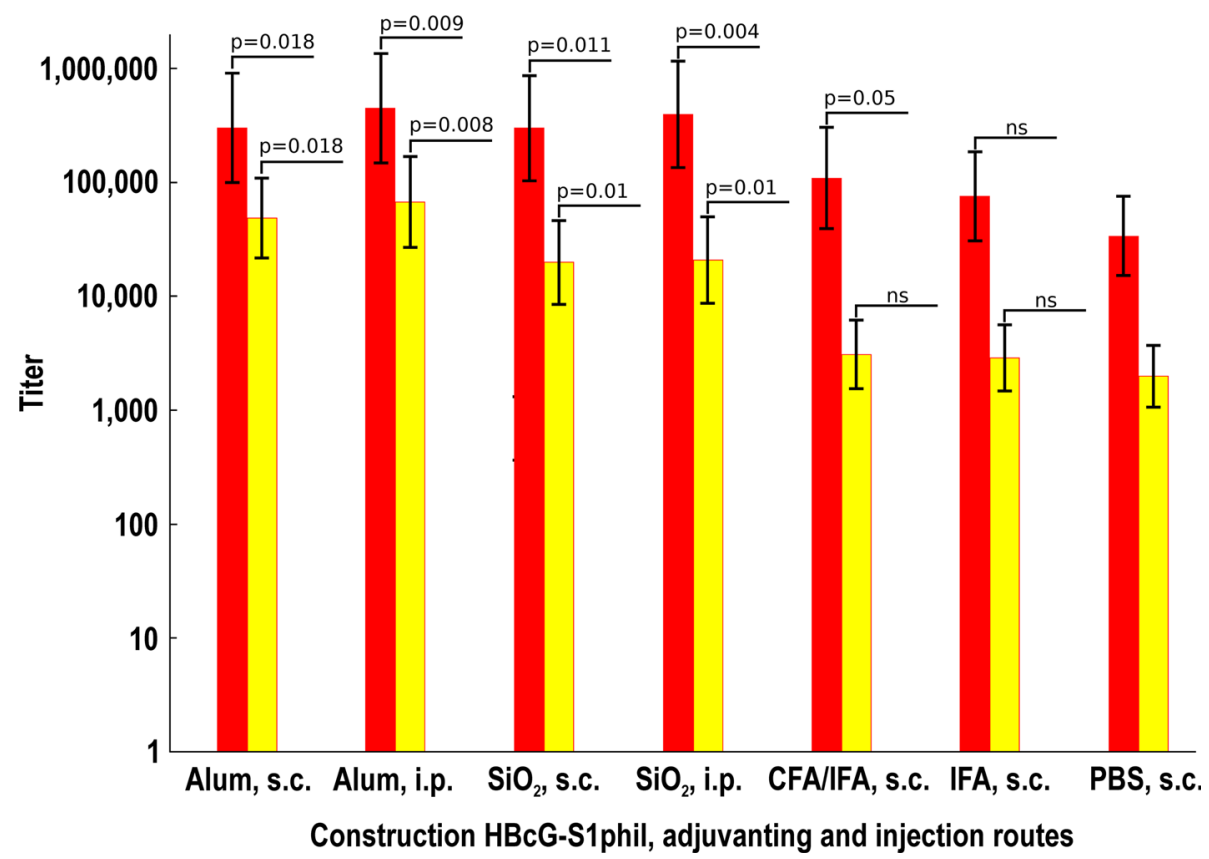

adjuvant recently [37]. The formulation of the $\mathrm{HBcG}-$ S1phil VLPs in CFA/IFA, IFA/IFA, or PBS resulted in much lower anti-preS1 and anti-HBc responses (Fig. 6). intraperitoneal immunisation route is preferable to the subcutaneous route. Second, the alum adjuvant was more efficient than the silica nanoparticles introduced by us as an 
The anti-preS1 titres were generally obtained by titrating the murine sera on the plates coated using the synthetic preS1(20-47) peptide. When recombinant full-length preS1 protein purified from E. coli cells (Petrovskis et al., not published) was used for coating, the anti-preS1 titres did not increase. In fact, the titres were lower for the fulllength protein than for the preS1(20-47) peptide. This difference may be due to the masking of the major preS1(31-35) epitope by the C-terminal preS1 sequences.

\section{Discussion}

The safe localisation of an inserted foreign epitope on the VLP surface is the first necessary step for the induction of an efficient humoral anti-epitope response after the immunisation of experimental animals by chimeric VLPs (for detailed review see $[3-8,38])$. The next important prerequisite consists in the self-assembly quality and the appropriate stability of the constructed chimeric VLPs carrying the foreign epitope in question. Here, we constructed a class of new $\mathrm{HBcG}$ vectors that permit the stable exposure of C-terminally added foreign epitopes on the high-quality VLPs and therefore fulfil both above-mentioned requirements. The $\mathrm{HBcG}$ vector in which all four C-terminal arginine stretches were replaced by glycine residues demonstrates not only maximal antigenicity (Fig. 4) and immunogenicity (Fig. 5) for the inserted preS1 epitope but also highly stable chimeric HBcGpreS1 VLPs during long-term storage (Renhofa et al., in preparation). Both the antigenicity and immunogenicity of the HBcG-preS1 VLPs was comparable with that of HBcderived VLPs carrying the preS1 epitope insertions within the HBc MIR (Fig. 5).

The fact that the substitution of the arginine motifs at the $\mathrm{C}$-terminus with alanine residues may induce a conformational change that allows C-terminal insertions to become more exposed and more immunogenic on the VLP surface has been demonstrated recently for the woodchuck hepatitis core (WHc) VLPs by the David Milich group [39]. In contrast to the MIR insertions, the foreign epitopes added to the C-terminus of the $\mathrm{HBcG}$ vector were much more flexible because the inserted epitope sequences remained linear with an unfixed C-terminus. This flexibility is especially important when $\mathrm{HBcG}$ vectors are used to insert cell receptor-recognising tools to target the packaged VLP nanocontainers to specific cell types. The $\mathrm{HBcG}$ vectors carrying one or two residual arginine stretches can present the preS1 epitope on the VLP surface to a lesser extent, but their ability to bind nucleic acids differs. If the $\mathrm{HBcG}_{-2^{-}}$ S1phil construct binds some nucleic acids, no bands are visible in ethidium bromide-stained agarose gels for the $\mathrm{HBcG}_{-2}-\mathrm{S} 1(20-47), \quad \mathrm{HBcG}_{-1}$-S1phil, and $\mathrm{HBcG}_{-1^{-}}$ S1(20-47) proteins. However, the ability to package nucleic acids is an obligatory prerequisite for the recently described use of VLP vectors as putative nanocontainers for genes and/or immunostimulatory oligonucleotide sequences [9]. As expected the ability to package nucleic acids was not reduced in $\mathrm{HBc}$-Gly vectors that retained the native full-length $\mathrm{C}$-terminus extended by a copy of the glycine-exchanged C-terminus, i.e. the so-called "two-tail" constructs HBc-Gly-S1(20-47) and HBc-Gly-S1phil. Notably, these vectors also demonstrated a clear ability to provide the preS1 sequences with definite immunogenic activity (Fig. 5). Like the original $\mathrm{HBc} \mathrm{C}$-terminal insertions $[3-8,29]$, we expected the high capacity of C-terminal insertions in case of $\mathrm{HBcG}$ and $\mathrm{HBc}-\mathrm{Gly}$ vectors. This hypothesis was supported by the successful insertion of the 80-aa-long preS1phil sequence demonstrated herein, which resulted in well self-assembled and stable VLPs (Fig. 3).

The remarkable advantage of the HBcG-based VLPs consists of their ability to endure the removal of the packaged traces of bacterial RNA (Renhofa, preliminary data) via the recently described alkali treatment procedure [9]. This ability promises not only an easier purification procedure but also presents a clear background for the standardisation and quality control of final biotechnological products. However, we need to remember that the VLPpackaged RNAs play a role of the TLR-7 ligand during immune response in mice [40]. Therefore, the knowledgebased providing of the RNA-free VLPs with the respective activities is one of the most important issues for the future.

The HBcG vectors retained the natural structure of the $\mathrm{HBc}$ MIR, which is important for cases that require a high immunological anti- $\mathrm{HBc}$ response in parallel with a foreign epitope-induced response. Moreover, the $\mathrm{HBcG}$ vectors permit the simultaneous application of two efficient sites: the MIR and C-terminus for the simultaneous exposure of two foreign epitopes or a pair of an epitope and a celltargeting signal.

We selected the preS1 immunodominant epitope as the model epitope in this work. This immunodominant epitope could take the following form: (i) a pure epitope corresponding to aa residues 31-35, (ii) an extended epitope 20-47, and (iii) a preS1phil sequence $12-60$ plus 89-119 aa corresponding to the full-length hydrophilic component of the preS1 sequence of the HBV of genotype D1, subtype ayw2 [34], in which the hydrophobic 61-88 stretch was deleted [30]. This major preS1 epitope is recognised by the highly specific antibody MA18/7 [33] and has been mapped as a linear 31-DPAFR-35 stretch [35, 36]. Antibodies elicited against this epitope in immunised animals are strongly virus-neutralising [41].

Below, the detection of the preS1 epitope by the MA18/ 7 antibody on the VLP surface is elaborated in detail. The preS1 epitope has been used as a model epitope not only 
for the fine mapping of the HBc VLP surface but also to map the RNA phage Q $\beta$ [42], DNA phage T7 [43], potato virus $\mathrm{Y}$ [44], polyomavirus [30, 45], human papillomavirus [46], and retrovirus [47] VLPs.

For HBc VLPs, the preS1 sequences 31-DPAFR-35 [12, 42, 48-50], 27-53 [28], 21-47 [51, 52], 20-47 [31], 1-42 [53], preS1phil [30], and the full-length preS1 [54] were inserted into the $\mathrm{HBc}$ MIR and appeared on the outer surface of the produced HBc-preS1 VLPs. The exposure on the HBc VLP surface was also demonstrated for N-terminal additions of the preS1 sequences [28, 55, 56]. In our experiments, the C-terminal additions of long preS1 sequences [57-60] resulted in the following: (i) contradictory preS1 antigenicity that strongly depended on the quality of the chimeric VLPs and (ii) negligible anti-preS1 immunogenicity when the quality of VLPs was satisfactory. The low immunogenicity of the C-terminally added preS1 sequences correlated well with the generally low level of exposure and immunological activity of C-terminal additions of many other epitopes to the HBc VLPs (for review see [4-6, 28] ).

Here, both preS1(20-47) and preS1phil sequences were able to induce a remarkable anti-preS1 response when incorporated into $\mathrm{HBcG}$ vectors, whereas the pure preS1(31-35) epitope was neither exposed on the VLP surface nor able to induce anti-preS1 antibodies.

Concerning differences of the anti-preS1 titers obtained in ELISA on two different supports, the antigenic quality of the full-length preS1 protein could be lowered by masking of the 20-47 stretch by other protein parts during coating on the solid support.

Because anti-preS1 epitope antibodies are virus-neutralising [41], the chimeric $\mathrm{HBcG}$-preS1 VLPs may serve as prototypes for the generation of a combined therapeutic and prophylactic anti-HBV vaccine in accordance with the current conception of the latter [61]. Moreover, the safe biotechnological background of the purification and standardisation protocols underlines the possible practical application of the elaborated $\mathrm{HBcG}$ vectors for the construction of prophylactic and/or therapeutic vaccines as well as advanced cell-targeting and gene therapy tools.

Acknowledgments We thank Mrs. Inara Akopjana for performing the E. coli transformations and preparing the bacteria for $\mathrm{HBc}$ VLP purification. This work was supported by a European Regional Development Foundation Grant 2013/0053/2DP/2.1.1.1.0/13/APIA/ VIAA/006.

Open Access This article is distributed under the terms of the Creative Commons Attribution 4.0 International License (http://creative commons.org/licenses/by/4.0/), which permits unrestricted use, distribution, and reproduction in any medium, provided you give appropriate credit to the original author(s) and the source, provide a link to the Creative Commons license, and indicate if changes were made.

\section{References}

1. Clarke, B. E., Newton, S. E., Carroll, A. R., Francis, M. J., Appleyard, G., Syred, A. D., et al. (1987). Improved immunogenicity of a peptide epitope after fusion to hepatitis B core protein. Nature, 330, 381-384.

2. Borisova, G., Bundule, M., Grinstein, E., Dreilina, D., Dreimane, A., Kalis, J., et al. (1987). Recombinant capsid structures for exposure of protein antigenic epitopes. Molecular Genetics, 6, 169-174.

3. Peyret, H., Stephen, S., Stonehouse, N. J., \& Rowlands, D. J. (2015). History and potential of hepatitis B virus core as a VLP vaccine platform. In Y. Khudyakov \& P. Pumpens (Eds.), Viral nanotechnology (pp. 177-186). Boca Raton: CRC Press.

4. Pumpens, P., \& Grens, E. (2001). HBV core particles as a carrier for B cell/T cell epitopes. Intervirology, 44, 98-114.

5. Pumpens, P., Ulrich, R., Sasnauskas, K., Kazaks, A., Ose, V., \& Grens, E. (2008). Construction of novel vaccines on the basis of the virus-like particles: Hepatitis B virus proteins as vaccine carriers. In Y. Khudyakov (Ed.), Medicinal protein engineering (pp. 205-248). Boca Raton: CRC Press.

6. Pushko, P., Pumpens, P., \& Grens, E. (2013). Development of virus-like particle technology from small highly symmetric to large complex virus-like particle structures. Intervirology, 56, 141-165.

7. Roose, K., De Baets, S., Schepens, B., \& Saelens, X. (2013). Hepatitis B core-based virus-like particles to present heterologous epitopes. Expert Review of Vaccines, 12, 183-198.

8. Zeltins, A. (2013). Construction and characterization of virus-like particles: A review. Molecular Biotechnology, 53, 92-107.

9. Strods, A., Ose, V., Bogans, J., Cielens, I., Kalnins, G., Radovica, I., et al. (2015). Preparation by alkaline treatment and detailed characterisation of empty hepatitis B virus core particles for vaccine and gene therapy applications. Scientific Reports, 5, 11639.

10. Crowther, R. A., Kiselev, N. A., Böttcher, B., Berriman, J. A., Borisova, G. P., Ose, V., \& Pumpens, P. (1994). Three-dimensional structure of hepatitis $\mathrm{B}$ virus core particles determined by electron cryomicroscopy. Cell, 77, 943-950.

11. Wynne, S. A., Crowther, R. A., \& Leslie, A. G. (1999). The crystal structure of the human hepatitis B virus capsid. Molecular Cell, 3, 771-780.

12. Roseman, A. M., Borschukova, O., Berriman, J. A., Wynne, S. A., Pumpens, P., \& Crowther, R. A. (2012). Structures of hepatitis $\mathrm{B}$ virus cores presenting a model epitope and their complexes with antibodies. Journal of Molecular Biology, 423, 63-78.

13. Kniskern, P. J., Hagopian, A., Montgomery, D. L., Burke, P., Dunn, N. R., Hofmann, K. J., et al. (1986). Unusually high-level expression of a foreign gene (hepatitis B virus core antigen) in Saccharomyces cerevisiae. Gene, 46, 135-141.

14. Miyanohara, A., Imamura, T., Araki, M., Sugawara, K., Ohtomo, N., \& Matsubara, K. (1986). Expression of hepatitis B virus core antigen gene in Saccharomyces cerevisiae: Synthesis of two polypeptides translated from different initiation codons. Journal of Virology, 59, 176-180.

15. Rolland, D., Gauthier, M., Dugua, J. M., Fournier, C., Delpech, L., Watelet, B., et al. (2001). Purification of recombinant $\mathrm{HBc}$ antigen expressed in Escherichia coli and Pichia pastoris: Comparison of size-exclusion chromatography and ultracentrifugation. Journal of Chromatography B: Biomedical Sciences and Applications, 753, 51-65.

16. Freivalds, J., Dislers, A., Ose, V., Pumpens, P., Tars, K., \& Kazaks, A. (2011). Highly efficient production of phosphorylated 
hepatitis B core particles in yeast Pichia pastoris. Protein Expression and Purification, 75, 218-224.

17. Birnbaum, F., \& Nassal, M. (1990). Hepatitis B virus nucleocapsid assembly: Primary structure requirements in the core protein. Journal of Virology, 64, 3319-3330.

18. Seifer, M., \& Standring, D. N. (1994). A protease-sensitive hinge linking the two domains of the hepatitis B virus core protein is exposed on the viral capsid surface. Journal of Virology, 68, 5548-5555.

19. Watts, N. R., Conway, J. F., Cheng, N., Stahl, S. J., Belnap, D. M., Steven, A. C., \& Wingfield, P. T. (2002). The morphogenic linker peptide of $\mathrm{HBV}$ capsid protein forms a mobile array on the interior surface. EMBO Journal, 21, 876-884.

20. Nassal, M. (2015). HBV cccDNA: Viral persistence reservoir and key obstacle for a cure of chronic hepatitis B. Gut,. doi:10.1136/ gutjnl-2015-309809.

21. Nassal, M. (1992). The arginine-rich domain of the hepatitis B virus core protein is required for pregenome encapsidation and productive viral positive-strand DNA synthesis but not for virus assembly. Journal of Virology, 66, 4107-4116.

22. Sominskaya, I., Skrastina, D., Petrovskis, I., Dishlers, A., Berza, I., Mihailova, M., et al. (2013). A VLP library of C-terminally truncated Hepatitis B core proteins: Correlation of RNA encapsidation with a Th1/Th2 switch in the immune responses of mice. PLOS ONE, 8, e75938.

23. Hatton, T., Zhou, S., \& Standring, D. N. (1992). RNA- and DNAbinding activities in hepatitis B virus capsid protein: A model for their roles in viral replication. Journal of Virology, 66, 5232-5241.

24. Machida, A., Ohnuma, H., Takai, E., Tsuda, F., Tanaka, T., Naito, M., et al. (1989). Antigenic sites on the arginine-rich carboxyl-terminal domain of the capsid protein of hepatitis B virus distinct from hepatitis B core or e antigen. Molecular Immunology, 26, 413-421.

25. Bundule, M. A., Bychko, V. V., Saulitis, Iu B, Liepinsh, E. E., Borisova, G. P., Petrovski, I. A., et al. (1990). C-terminal polyarginine tract of hepatitis B core antigen is located on the outer capsid surface (Article in Russian). Doklady Akademii Nauk SSSR, 312, 993-996.

26. Vanlandschoot, P., Van Houtte, F., Serruys, B., \& Leroux-Roels, G. (2005). The arginine-rich carboxy-terminal domain of the hepatitis B virus core protein mediates attachment of nucleocapsids to cell-surface-expressed heparan sulfate. Journal of General Virology, 86, 75-84.

27. Meng, D., Hjelm, R. P., Hu, J., \& Wu, J. (2011). A theoretical model for the dynamic structure of hepatitis B nucleocapsid. Biophysical Journal, 101, 2476-2484.

28. Schödel, F., Moriarty, A. M., Peterson, D. L., Zheng, J. A., Hughes, J. L., Will, H., et al. (1992). The position of heterologous epitopes inserted in hepatitis B virus core particles determines their immunogenicity. Journal of Virology, 66, 106-114.

29. Yon, J., Rud, E., Corcoran, T., Kent, K., Rowlands, D., \& Clarke, B. (1992). Stimulation of specific immune responses to simian immunodeficiency virus using chimeric hepatitis B core antigen particles. Journal of General Virology, 73, 2569-2575.

30. Skrastina, D., Bulavaite, A., Sominskaya, I., Kovalevska, L., Ose, V., Priede, D., et al. (2008). High immunogenicity of a hydrophilic component of the hepatitis B virus preS1 sequence exposed on the surface of three virus-like particle carriers. Vaccine, 26, 1972-1981.

31. Sominskaya, I., Skrastina, D., Dislers, A., Vasiljev, D., Mihailova, M., Ose, V., et al. (2010). Construction and immunological evaluation of multivalent hepatitis B virus (HBV) core virus-like particles carrying $\mathrm{HBV}$ and $\mathrm{HCV}$ epitopes. Clinical and Vaccine Immunology, 17, 1027-1033.
32. Ehresmann, B., Imbault, P., \& Weil, J. H. (1973). Spectrophotometric determination of protein concentration in cell extracts containing tRNA's and rRNA's. Analytical Biochemistry, 54, 454-463.

33. Heermann, K. H., Goldmann, U., Schwartz, W., Seyffarth, T., Baumgarten, H., \& Gerlich, W. H. (1984). Large surface proteins of hepatitis B virus containing the pre-s sequence. Journal of Virology, 52, 396-402.

34. Bichko, V., Pushko, P., Dreilina, D., Pumpen, P., \& Gren, E. (1985). Subtype ayw variant of hepatitis B virus. DNA primary structure analysis. FEBS Letters, 185, 208-212.

35. Sominskaya, I., Pushko, P., Dreilina, D., Kozlovskaya, T., \& Pumpen, P. (1992). Determination of the minimal length of preS1 epitope recognized by a monoclonal antibody which inhibits attachment of hepatitis B virus to hepatocytes. Medical Microbiology and Immunology, 181, 215-226.

36. Germaschewski, V., \& Murray, K. (1995). Screening a monoclonal antibody with a fusion-phage display library shows a discontinuity in a linear epitope within PreS1 of hepatitis B virus. Journal of Medical Virology, 45, 300-305.

37. Skrastina, D., Petrovskis, I., Lieknina, I., Bogans, J., Renhofa, R., Ose, V., et al. (2014). Silica nanoparticles as the adjuvant for the immunisation of mice using hepatitis B core virus-like particles. PLOS ONE, 9, e114006.

38. Whitacre, D. C., Lee, B. O., \& Milich, D. R. (2009). Use of hepadnavirus core proteins as vaccine platforms. Expert Review of Vaccines, 8, 1565-1573.

39. Whitacre, D., Espinosa, D., Peterson, D., Zavala, F., \& Milich, D. R. (2015). Use of VLPs in the design of malaria vaccines. In Y. Khudyakov \& P. Pumpens (Eds.), Viral nanotechnology (pp. 209-231). Boca Raton: CRC Press.

40. Lee, B. O., Tucker, A., Frelin, L., Sallberg, M., Jones, J., Peters, C., et al. (2009). Interaction of the hepatitis B core antigen and the innate immune system. Journal of Immunology, 182, 6670-6681.

41. Bremer, C. M., Sominskaya, I., Skrastina, D., Pumpens, P., El Wahed, A. A., Beutling, U., et al. (2011). N-terminal myristoylation-dependent masking of neutralizing epitopes in the preS1 attachment site of hepatitis B virus. Journal of Hepatology, 55, 29-37.

42. Fehr, T., Skrastina, D., Pumpens, P., \& Zinkernagel, R. M. (1998). T cell-independent type I antibody response against B cell epitopes expressed repetitively on recombinant virus particles. Proceedings of the National Academy of Sciences of the United States of America, 95, 9477-9481.

43. Tang, K. H., Yusoff, K., \& Tan, W. S. (2009). Display of hepatitis B virus PreS1 peptide on bacteriophage T7 and its potential in gene delivery into HepG2 cells. Journal of Virological Methods, 159, 194-199.

44. Kalnciema, I., Skrastina, D., Ose, V., Pumpens, P., \& Zeltins, A. (2012). Potato virus Y-like particles as a new carrier for the presentation of foreign protein stretches. Molecular Biotechnology, 52, 129-139.

45. Gedvilaite, A., Frömmel, C., Sasnauskas, K., Micheel, B., Ozel, M., Behrsing, O., et al. (2000). Formation of immunogenic viruslike particles by inserting epitopes into surface-exposed regions of hamster polyomavirus major capsid protein. Virology, 273, $21-35$.

46. Joshi, H., Lewis, K., Singharoy, A., \& Ortoleva, P. J. (2013). Epitope engineering and molecular metrics of immunogenicity: A computational approach to VLP-based vaccine. Vaccine, 31, 4841-4847.

47. Qi, P., Han, J. X., Lu, Y. Q., \& Wang, C. X. (2007). Redirecting retroviral tropism by insertion of hepatitis B virus PreS1 core peptide into the envelope. Archives of Virology, 152, 1721-1730. 
48. Pushko, P., Sallberg, M., Borisova, G., Ruden, U., Bichko, V., Wahren, B., et al. (1994). Identification of hepatitis B virus core protein regions exposed or internalized at the surface of $\mathrm{HBcAg}$ particles by scanning with monoclonal antibodies. Virology, 202, 912-920.

49. Makeeva, I. V., Kalinina, T. I., Khudiakov, Iu E, Samoshin, V. V., Smirnova, E. A., Semiletov, Iu A, et al. (1995). Heterologous epitopes in the central part of the hepatitis B virus core protein (Article in Russian). Molekuliarnaia Biologiia (Moskva), 29, 211-224.

50. Borisova, G., Borschukova, O., Skrastina, D., Dislers, A., Ose, V., Pumpens, P., \& Grens, E. (1999). Behavior of a short preS1 epitope on the surface of hepatitis B core particles. Biological Chemistry, 380, 315-324.

51. Su, Q. D., Guo, M. Z., Yi, Y., Chen, S. Y., Jia, Z. Y., Lu, X. X., et al. (2013). Antigenic analysis of two chimeric hepatitis B core particles presenting the preS1 neutralizing epitopes (Article in Chinese). Zhonghua Shi Yan He Lin Chuang Bing Du Xue Za Zhi, 27, 336-339.

52. Yang, H. J., Chen, M., Cheng, T., He, S. Z., Li, S. W., Guan, B. Q., et al. (2005). Expression and immunoactivity of chimeric particulate antigens of receptor binding site-core antigen of hepatitis B virus. World Journal of Gastroenterology, 11, 492-497.

53. Malik, I. R., Chen, A., Brass, A., Ahlén, G., Rahman, M., Sällberg, M., et al. (2012). A bi-functional hepatitis B virus core antigen $(\mathrm{HBcAg})$ chimera activates $\mathrm{HBcAg}$-specific $\mathrm{T}$ cells and preS1-specific antibodies. Scandinavian Journal of Infectious Diseases, 44, 55-59.

54. Kazaks, A., Borisova, G., Cvetkova, S., Kovalevska, L., Ose, V., Sominskaya, I., et al. (2004). Mosaic hepatitis B virus core particles presenting the complete preS sequence of the viral envelope on their surface. Journal of General Virology, 85, 2665-2670.
55. Kalinina, T. I., Makeeva, I. V., Khudiakov, Iu E, Samoshin, V. V., Smirnova, E. A., Semiletov, Iu A, et al. (1995). Introduction of heterologous epitopes at the N-terminal part of the hepatitis B core protein (Article in Russian). Molekuliarnaia Biologiia (Moskva), 29, 199-210.

56. Lee, K. W., Tey, B. T., Ho, K. L., \& Tan, W. S. (2012). Delivery of chimeric hepatitis B core particles into liver cells. Journal of Applied Microbiology, 112, 119-131.

57. Stahl, S. J., \& Murray, K. (1989). Immunogenicity of peptide fusions to hepatitis B virus core antigen. Proceedings of the National Academy of Sciences of the United States of America, $86,6283-6287$.

58. Borisova, G. P., Berzins, I., Pushko, P. M., Pumpen, P., Gren, E. J., Tsibinogin, V. V., et al. (1989). Recombinant core particles of hepatitis B virus exposing foreign antigenic determinants on their surface. FEBS Letters, 259, 121-124.

59. Borisova, G. P., Berzin', I. G., Tsibinogin, V. V., Loseva, V. Ia., Pushko, P. M., Ose, V. P., et al. (1990). Hepatitis B core antigen as a carrier of functionally active epitopes: exposure of pre-S sites on capsids (Article in Russian). Doklady Akademii Nauk SSSR, 312, 751-754.

60. Chen, X., Li, M., Le, X., Ma, W., \& Zhou, B. (2004). Recombinant hepatitis $\mathrm{B}$ core antigen carrying preS1 epitopes induce immune response against chronic HBV infection. Vaccine, 22, 439-446.

61. Gerlich, W. H. (2015). Prophylactic vaccination against hepatitis B: Achievements, challenges and perspectives. Medical Microbiology and Immunology, 204, 39-55. 